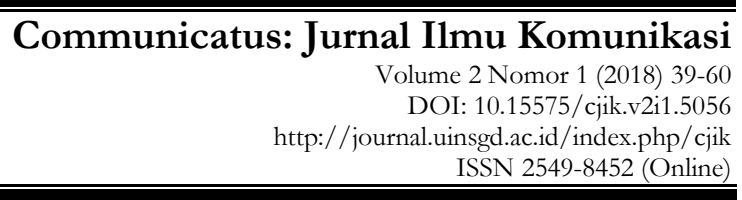

\title{
Strategi Komunikasi untuk Meningkatkan Kesadaran Masyarakat dalam Membayar Zakat Maal
}

\author{
${ }^{1}$ Asep Sudarman \\ ${ }^{1}$ Kementerian Agama, Kota Bandung \\ *email.asepanom73@gmail.com
}

\begin{abstract}
Poverty is a very serious problem faced by the Indonesian people and to immediately find and find solutions to reduce a problem in poverty. Zakat is one way to reduce poverty, by utiliqing the rakat funds. Zakat Collector Unit (UPZ) in Rancasari Sub-District, Bandung City, is devoted to rakat management activities in conveying messages so that the public is aware of the importance of paying zakat mal if it is bishab and haul. So that a number of questions were formulated in the study: 1) What is the Communication Strategy in Planning? 2) What is the Communication Strategy in Implementation? 3) What is the Communication Strategy in Evaluation? The theory used in this study is a management approach communication strategy from Fred R. David which reveals that the strategy management process has three stages: Planning, Implementation and Evaluation. This theory is also strengthened by the communication strategy of Richard West Lynn H. Tunner with internal and external communication approaches. The method used in this study is observation, in-depth interviews and documentation. The results of this study: Planning both internally and externally is supported by the role of the chairman who carries out organizational command by optimizing existing fields. Implementation of the Zakat Collection Unit in Rancasari Subdistrict is still on activities outside rakat mall. Trust in the Zakat Collection Unit is still lacking. Socialization activities are still at the level of verbal delivery in certain groups or forums.
\end{abstract}

Keywords: poverty; Zakat; Strategi;

\begin{abstract}
ABSTRAK
Kemiskinan merupakan masalah yang sangat serius yang dihadapi oleh bangsa Indonesia dan untuk segera mencari dan menemukan solusi untuk mengurangi suatu persoalan dalam kemiskinan tersebut. Zakat merupakan salah satu cara untuk menekan angka kemiskinan, dengan memanfaatkan dana zakat tersebut. Unit Pengumpul Zakat (UPZ) Kecamatan Rancasari Kota Bandung pada kegiatan pengelolaan zakat maal dikhususkan dalam menyampaikan pesan agar masyarakat menyadari pentingnya membayar zakat mal bila sudah bishab dan haul. Sehingga dirumuskan beberapa pertanyaan dalam penelitian: 1) Bagaimana Strategi Komunikasi dalam Perencanaan? 2) Bagaimana Strategi Komunikasi dalam Implementasi? 3) Bagaimana Strategi Komunikasi dalam Evaluasi? Teori yang digunakan dalam penelitian ini adalah strategi komunikasi pendekatan manajemen dari Fred R. David yang mengungkapkan bahawa proses manajemen strategi ada tiga tahapan yakni: Perencanaan, Implementasi dan
\end{abstract}


Asep Sudarman

Evaluasi. Teori ini juga dikuatkan oleh strategi komunikasi dari Richard West Lynn H. Tunner dengan pendekatan komunikasi internal dan eksternal. Metode yang digunakan dalam penelitian ini dalah observasi, wawancara mendalam dan dokumentasi. Hasil dari penelitian ini: Perencanaan baik secara internal dan eksternal didukung oleh peran ketua yang menjalankan komando organisasi dengan mengoptimalkan bidang-bidang yang ada. Pelaksanaan implementasi Unit Pengumpul Zakat Kecamatan Rancasari masih pada kegiatan diluar zakat mal. Kepercayaan kepada Unit Pengumpul Zakat masih kurang. Kegiatan sosialisasi pun masih pada tataran penyampaian secara verbal pada kumpulan atau forum tertentu.

Kata kunci: kata kunci 1; kata kunci 2; kata kunci 3.

\section{PENDAHULUAN}

Kemiskinan merupakan masalah yang sangat serius yang dihadapi oleh bangsa Indonesia dan untuk segera mencari dan menemukan solusi untuk mengurangi suatu persoalan dalam kemiskinan tersebut. Zakat merupakan salah satu cara untuk menekan angka kemiskinan, dengan memanfaatkan dana zakat tersebut. Pengurangan angka kemiskinan bagi Islam dibuktikan dengan zakat yang dijadikan oleh Allah SWT sebagai sumber jaminan hak-hak orang-orang fakir, miskin dan mustahik lainnya sebagai bagian dari salah satu rukun Islam.

Zakat dalam aspek sosial ekonomi merupakan suatu instrument yang dapat meredistribusikan penghasilan atau rezeki yang berlebihdari mereka yang memiliki kelebihan rezekidengan mereka yang berkekurangan. Sehingga dengan zakat ini kesenjangan pendapatan antara kelompok masyarakat kaya dengan masyarakat miskin dapat diminimalisasi. Bagaimanapun, ukuran kaya dan miskin dalam Islam sangat jelas dilihat dari garis nisabnya. Jika kepemilikan seseorang berada di bawah garis nisab maka termasuk dalam kategori miskin (mustabik). Sebaliknya jika berada di atas garis nisab, maka termasuk dalam kelompok non miskin yang berarti wajib menunaikan zakat (muzakki).

Zakat, infak, sedekah dan dana sosial keagamaan lainnya yang dihimpun BAZNAS, disalurkan kepada orang-orang yang berhak menerima (mustabik) sesuai ketentuan syariat Islam. Penyaluran zakat diperuntukkan untuk 8 (delapan) asnaf, yaitu fakir, miskin, amilin, muallaf, gharimin, riqab, fisabilillah dan ibnu sabil. Penyaluran dana umat yang dikelola oleh Badan Amil Zakat Nasional dilakukan dalam bentuk pendistribusian (konsumtif) dan pendayagunaan (produktif). Selain menyantuni, Badan Amil Zakat Nasional menanamkan semangat berusaha dan kemandirian kepada kaum miskin dan dhuafa yang masih bisa bekerja agar tidak selamanya bergantung dari dana zakat, ini bersinergi dari mulai tingkat provinsi sampai pada daerah yang dikelola oleh Unit Pengumpul Zakat.

Keberhasilan Badan Amil Zakat Nasional dalam meningkatkan pengumpulan zakat dari muqakki pada kegiatan komunikasi secara efektif banyak ditentukan oleh penentuan strategi komunikasi para amil kepada muzakki, baik 
Strategi Komunikasi Untuk Meningkatkan Kesadaran Masyarakat dalam Membayar Zakat Maal komunikasi interpersonal, intrapersonal maupun penyampaian isi pesan berkaitan dengan zakat maal yang disampaikan oleh Amil Zakat. Kepiawaian para amil zakat dalam berkomunikasi sangat menentukan keberhasilan pengumpulan zakat di Kecamatan Rancasari Kota Bandung, komunikasi efektif yang digunakan amil kepada muzakki dalam bingkai strategi komunikasi para amil zakat di Unit Pengumpul Zakat Kecamatan Rancasari Kota Bandung dapat berpengaruh besar kepada masyarakat terutama para muzakki untuk mengeluarkan zakatnya.

Fenomena ini terlihat pada kota Bandung yang termasuk dalam wilayah Provinsi Jawa Barat, meluncurkan gerakan ayo bayar zakat pertama di Indonesia tentunya telah melaksankan tugas, fungsi dan kedudukan. Sebagai bagian dari wilayah Jawa Barat. Persoalan tersebut sesuai dengan apa yang telah dicanangkan oleh walikota Bandung Ridwan Kamil dengan gerakan Ayo Bayar Zakat. Maka dengan program ini Unit Pengumpul Zakat (UPZ) Kecamatan Rancasari Kota Bandung berusaha keras untuk sebaik mungkin mensosialisasikan Zakat Maal sehingga masyarakat sadar akan pentingnya membayar zakat Maal yang dikelola oleh Unit Pengumpul Zakat, terlebih pada Zakat Maal yang berbeda dengan Zakat Fitrah dalam ketentuannya.

Fenomena semangat membayar zakat mal (zakat harta, bukan zakat fitrah) di bulan suci Ramadhan memang harus diluruskan. Karena fenomena ini telah menjadi satu kebiasaan masyarakat kita. Hal ini dikhawatirkan dapat membentuk opini di masyarakat awam nantinya, bahwa zakat hanya dibayar di bulan Ramadhan saja. Sebagian muzakki (wajib zakat), membayar zakat mal mereka di bulan Ramadhan.

Kebiasaan tersebut dapat terjadi secara kebetulan dan bisa juga melalui perencanaan dalam mengatur dan menghitung haul (berlalu waktu satu tahun) agar jatuh pada bulan Ramadhan dengan berbagai macam pertimbangan. Bagi muzakki yang kebetulan jatuh haul-nya di bulan Ramadhan biasanya para pedagang, peternak, pengusaha atau muzakki lainnya yang tanpa sengaja telah memulai usaha mereka pada Ramadhan sebelumnya, maka ketika Ramadhan berikutnya datang cukuplah perhitungan haul zakatnya dan mereka langsung menunaikannya setelah syarat-syarat lain terpenuhi tentunya.

Disebabkan pengelolaan Zakat Maal berbeda dalam kaidah fiqh sehingga perlu strategi khusus dalam mengkomunikasikannya. Selama ini Unit Pengumpul Zakat (UPZ) Kecamatan Rancasari Kota Bandung masih belum maksimal dalam pengelolaannya. Kegiatan yang biasa dilakukan masih menggunakan cara-cara lama seperti mengkomunikasikan melalui media mimbar dan majelis ta'lim saja.Sehingga dampaknya hanya sebatas informasi tanpa adanya tindak lanjut. Kegiatan tersebut berdampak pula pada kurangnya kesadaan masyarakat dalam menitipkan zakat maal. Maka dari itu, Unit Pengumpul Zakat (UPZ) Kecamatan Rancasari Kota Bandung memerlukan strategi khusus dalam pengelolaan qakat maal.

Kegiatan pengumpulan zakat yang dilaksanakan oleh Unit Pengumpul 
Asep Sudarman

Zakat Kecamatan Rancasari Kota Bandung biasa dilaksanakan dengan beberapa pola diantaranya: Unit Pengumpul Zakat berkoordinasi dengan seluruh jajaran dalam kepengurusan serta melibatkan penyuluh Agama Kecamatan Rancasari dan tokoh masyarakat untuk rapat koordinasi yang didalamnya menyamakan persepsi berkenaan dengan sosialisasi serta edukasi kepada masyarakat di Kecamatan Rancasari Kota Bandung. Kemudian, baik jajaran pengurus, penyuluh agama dan tokoh masyarakat bersama untuk menyampaikan hasil rapat koordinasi pada masyarakat.

Pengurus Unit Pengumpul Zakat dalam melaksanakan sosialisasi dan edukasi dalam pengumpulan zakat mal memanfaatkan media majelis ta'lim, tablihg akbar serta setiap kumpulan atau acara yang melibatan banyak warga. Selain itu Kantor Urusan Agama (KUA) menjadi sekretariat tempat berkumpul baik pengurus maupun masyarakat yang ingin menitipkan atau pun menanyakan informasi berkenaan dengan pengumpulan zakat maal.

Persoalan teori yang digunakan penelitian ini adalah teori manajemen strategis yang dikembangkan oleh Fred R. David. Teori ini dipandang relevan oleh peneliti untuk digunakan dalam penelitian ini karena teori ini menekankan pada aspek hubungan timbal balik dan berkelanjutan antara tahapan-tahapan dalam manajerial strategi komunikasi. Dalam konteks ini pencapaiannya adalah kesadaran dari masyarakat dalam menitipkan zakat maal oleh Unit Pengumpul Zakat (UPZ) Kecamatan Rancasari Kota Bandung sangat memerlukan suatu strategi komunikasi yang berkelanjutan.

Penelitian strategi komunikasi telah dilakukan oleh beberapa peneliti diantara (Ariyanto, 2019) meneliti terkait Strategi Komunikasi Dakwah dalam Pembinaan Mental Narapidana, dari penelitian tersebut disimpulkan bahwa, setelah diterapkannya strategi komunikasi dakwah oleh da'I yang disebutkan di atas kepada warga binaan di lapas, terjadi perubahan dari keadaan menyimpang menjadi sadar dan bersikap lebih baik dari sebelumnya serta menimbulkan efek jera. Penelitian lainnya berkaitan dengan strategi komunikasi dalam meningkatkan kesadaran kesehatan (Ginting \& Ellen, 2013). Hasil penelitian menunjukkan bahwa terdapat pengaruh yang signifikan antara Strategi Komunikasi Tim Penggerak PKK Pokja IV Terhadap Tingkat Kesadaran Masyarakat mengenai Kesehatan di Kelurahan Dendang Kecamatan Stabat Kabupaten Langkat. Penelitian tentang strategi komunikasi politik yang berkaitan dengan isu-isu keperempuanan (Handoko, 2009). Penelitian ini menganalisis bagaimana kampanye dilakukan dengan mengambil isu perempuan yang terjadi dalam momentum Pilkada.

Penelitian tentang strategi komunikasi juga dilakukan dengan sudut pandang politik (Satma, 2018). Penelitian ini mengambil fokus permasalahan berkaitan dengan strategi komunikasi KPUD Kota Padang dalam meningkatkan partisipasi pemilih pada Pemilu 2018. Hasil penelitian menunjukkan ada 
Strategi Komunikasi Untuk Meningkatkan Kesadaran Masyarakat dalam Membayar Zakat Maal peningkatan partisipasi pemilu di Kota Padang melalui berbagai saluran komunikasi yang dilakukan oleh KPU. Penelitian tentang strategi komunikasi Penyuluh lapangan Keluarga Berencana (Ani \& Sufiatni, 2013). Hasil penelitian menunjukkan bahwa komunikasi informasi dan edukasi yang berupa penyuluhan dengan memberikan pengetahuan kepada masyarakat dan mengunjungi rumah-rumah sekolah dan madrasah untuk mengikuti program kb, mengantisipasi kehamilan dini, mengatur jarak kelahiran dan menurunkan angka kematian bayi. Penelitian lainnya berkaitan dengan strategi komunikasi pengawas pendidikan menengah di dinas Pendidikan Kabupaten Gresik (Okprina, 2014). Penelitian ini terfokus pada optimalisasi supervisi pendidikan yang dilakukan oleh dinas sebagai sebuah strategi dalam melakukan pengawasan.

Penelitian lainnya tentang strategi komunikasi Lembaga Amil Zakat Ummah dalam meningkatkan jumlah muzakki di Pekanbaru (Hidayah, 2015). Hasil penelitian menunjukkan bahwa pola strategi komunikasi yang dilakukan adalah melalui komunikasi edukatif, persuasif dan informatif. Strategi ini dilakukan terhadap karyawan, tokoh dan masyarakat umum. Penelitian lainnya dilakukan berkaitan strategi komunikasi Badan Amil Zakat Nasional dalam pengumpulan zakat mal (Wardani, 2017). Hasil penelitian menunjukkan bahwa penerapan strategi komunikasi BAZ Jawa Barat dilakukan melalui ISO, Renstra dan RKAT BAZ propinsi Jawa Barat. Penelitian tentang system komunikasi internal organisasi (Imran, 2008). Penelitian ini mengkaji berkaitan tentang strategi komunikasi organisasi dalam menghadapi tantangan global. Penelitian berkaitan dengan stratgei komunikasi LSM dalam fundrising dana (Prasetya, 2011). Penelitian menyimpulkan bahwa strategi komunikasi yang dilakukan meliputi perencanaan, pemilihan media, pelaksanaan dan evaluasi. Penelitian tentang strategi komunikasi untuk mengatasi rintangan komunikasi debaters (Heddy \& Aruan, 2013). Hasil penelitian menunjukkan bahwa Rintangan komunikasi yang ditemukan adalah rintangan tata bahasa dan rintangan kefasihan. Untuk mengatasi rintangan tersebut, debaters menggunakan strategi retrieval, strategi $\hat{A}$ rephrase, dan strategi using formulaic expressions.

Penelitian ini menarik untuk dilanjutkan sebagai bahan analisa dan memberi masukan terhadap Unit Pengumpul Zakat (UPZ) Kecamatan Rancasari Kota Bandung pada kegiatan pengelolaan qakat maal dikhususkan dalam menyampaikan pesan agar masyarakat menyadari pentingnya membayar zakat mal bila sudah bishab dan haul. Pesan berkenaan dengan ketentuan membayar rakat maal yang dikelola oleh Unit Pengumpul Zakat (UPZ) Kecamatan Rancasari Kota Bandung. Sehingga dampaknya masyarakat menyadari peran dari lembaga bersangkutan sebagai pengelola zakat mal.

Berdasarkan latar belakang diatas, maka dapat di rumuskan penelitian ini untuk menjawab bagaimana Strategi komunikasi Unit Pengumpul Zakat Kecamatan Rancasari Kota bandung dalam meningkatkan kesadaran masyarakat untuk menitipkan zakat maal yang dirumuskan dalam pertanyaan dibawah ini. 
Bagaimana Strategi Komunikasi dalam Perencanaan yang digunakan oleh Unit Pengumpul Zakat Kecamatan Rancasari Kota Bandung baik secara internal dan eksternal? Bagaimana Strategi Komunikasi dalam Implementasi PengelolaanUnit Pengumpul Zakat Kecamatan Rancasari Kota Bandung secara internal dan eksternal? Bagaimana Strategi Komunikasi dalam Evaluasi Pengelolaan Unit Pengumpul Zakat Kecamatan Rancasari Kota Bandung secara internal dan eksternal?

\section{HASIL DAN PEMBAHASAN}

Mengacu pada rumusan masalah, penelitian ini terfokus pada aspek manajemen strategi, representasi bentuk komunikasi dan sosialisi untuk meningkatkan kesadaran menitipkan zakat maal Unit Pengumpul Zakat (UPZ) Kecamatan Rancasari Kota Bandung. Maka, berdasarkan fokus penelitian tersebut, kerangka pemikiran ini akan membahas tentang konsep dan teori yang berkaitan manajemen strategi, bentuk komunikasi, dan sosialisasi. Proses manajemen strategi belum data dikatakan selesai ketika perusahaan memutuskan strategi apa yang akan ditempuh. Perusahaan masih harus menterjemahkan rumusan strategi tersebut ke dalam tindakan stategi.

Persoalan pengimplementasian strategi yang harus selalu diingat bahwa sebaik apapun rumusan strategi, hanya akan menjadi retorika belaka jika tidak dapat diimplementasikan dengan baik. Oleh karena itu, agar perusahaan dapat mencapai tujuan secara optimal, maka selain harus mampu merumuskan strategi Perusahaan harus mampu mengimplememtasikan strategi tersebut secara efektif. Jika salah satu langkah tersebut tidak dapat dilaksanakan dengan baik maka mustahil perusahaan akan mencapai target yang diinginkan.

Banyak perusahaan atau organisasi yang banyak menghamburkan sumberdayanya (uang, waktu, tenaga) untuk mengembangkan rencana strategi yang "ampuh". Namun kita harus ingat bahwa perubahan hanya akan terjadi melalui suatu action (implementasi), bukan sekedar perencanaan. Rumusan strategi yang secara teknis kurang sempurna jika diimplementasikan dengan baik, maka akan didapat hasil yang lebih baik dibandingkan dengan rumusan strategi yang sempurna namun hanya " di atas kertas". didukung oleh sebuah hasil penelitian pada 31 industri manufaktur di mana hasilnya menunjukkan bahwa kinerja yang diperoleh perusahaan tidak sekedar ditentukan oleh strategi yang dimiliki, namun lebih disebabkan karena efektivitas perusahaan dalam mengimplementasikan strategi tersebut (Certo \& Peter, 1990:120).

Onong Uchjana Effendy (2007:32) mengungkapkan strategi pada hakikatnya adalah perencanaan (planning) dan manajemen (management) untuk mencapai suatu tujuan. Akan tetapi, untuk mencapai tujuan tersebut, strategi tidak berfungsi sebagai peta jalan yang hanya menunjukan arah saja, melainkan harus mampu menunjukan bagaimana taktik operasionalnya. Strategi komunikasi 
Strategi Komunikasi Untuk Meningkatkan Kesadaran Masyarakat dalam Membayar Zakat Maal mencakup berbagai kemampuan interaksional yang meliputi kompetensi gramatikal, kompetensi konversasional, kompetensi social dan kompetensi komunikatif (Indrariani, 2011: 78).

Strategi komunikasi dapat juga dikatakan sebagai paduan perencanaan komunikasi (communication planning) dan manajemen komunikasi (communication management) untuk mencapai suatu tujuan yang telah ditetapkan. Arifin Anwar (1984:87) Menyatakan bahwa elemen yang harus diperhatikan didalam merumuskan strategi komunikasi adalah pengenalan khalayak, pesan, metode, media, dan komunikator. Sumber lain menyebutkan bahwa strategi adalah pendekatan secara keseluruhan yang berkaitan dengan pelaksanaan gagasan, perencanaan dan eksekusi sebuah aktivitas dalam kurun waktu tertentu. Menurut Rangkuti, strategi adalah alat untuk mencapai tujuan, tujuan utamanya agar perusahaan dapat melihat secara objektif kondisi internal dan eksternal (Rangkuti, 2009: 3). Strategi dalam pemilihan komunikator, penentuan audience, pemakaian bahasa dan simbol dalam pesan, dan media, sangat mempengaruhi keberhasilan proses komunikasi. Apabila strategi yang digunakan hanya terbatas pada penggunaan satu atau beberapa faktor saja atau tidak menggunakan faktorfaktor yang ada didalamnya dengan benar maka hasilnya pun tidak akan maksimal. Strategi komunikasi adalah pilihan dari berbagai langkah agar upaya dan daya yang digunakan dapat secara efektif dan efesien (Anggraningrum, 2014: 4).

Proses manajemen strategi belum data dikatakan selesai ketika perusahaan memutuskan strategi apa yang akan ditempuh. Perusahaan masih harus menterjemahkan rumusan strategi tersebut ke dalam tindakan stategi. Persoalan pengimplementasian strategi yang harus selalu diingat bahwa sebaik apapun rumusan strategi, hanya akan menjadi retorika belaka jika tidak dapat diimplementasikan dengan baik. Oleh karena itu, agar perusahaan dapat mencapai tujuan secara optimal, maka selain harus mampu merumuskan strategi. Prinsip-prinsip pemakaian strategi komunikasi pembangunan untuk menghindari kemungkinan efek-efek yang tidak diinginkan ada beberapa, yakni penggunaan saluran tradisional, pengenalan pemimpin, penyampaian pesan, pendekatan pesan, pemilihan pesan, dan pemilihan media (Rahmawati, Suryandari, \& Kurniasari, 2013: 36).

Corder (1983) berpendapat bahwa strategi komunikasi adalah teknik yang sistematis dan digunakan pembelajar untuk mengekspresikan idenya ketika mengalami kesulitan karena penguasaan bahasa yang belum sempurna (Werdiningsih, 2010: 103). Seperti yang disebutkan diatas persoalan manajemen komunikasi terhadap visi dan misi dalam mengumpulkan zakat maal, memerlukan seperangkat teori yang mendukung. Supaya pengelolaan Zakat oleh Unit Pengumpul Zakat (UPZ) Kecamatan Rancasari Kota Bandung mencapai target yang ingin dicapai.Menurut Belch George \& Belch Michael (Belch \& Belch, 2007: 21-30) komponen-komponen dalam efek kognitif untuk 
menunjang pengumpulan yaitu:

Awarenees (kesadaran). Jika sebagaian besar audience sasaran tidak menyadari merek atau produk atau jasa, yang ditawarkan, tugas perusahaan adalah membangun kesadaran. Kesadaran berarti bahwa pesan yang telah dibuat menimbulkan kesan kepada pembaca atau penonton yang kemudian dapat membantu mengidentifikasi pembuat pesan.

Knowledge ( Pengetahuan). Audience mungkin telah memiliki kesadaran, tetapi tidak mengetahui lebih banyak lagi. Unit Pengumpul Zakat (UPZ) Kecamatan Rancasari Kota Bandung memiliki tugas untuk memberikan informasi sebanyak-banyaknya sehingga audience sasaran memiliki "pengetahuan tentang produk, manfaat, faedah guna, dan keuntungan, serta bagaimana cara menggunakan produk" (Beadle, 2013: 21-30)

Ketika menentukan efek apa yang dikehendaki dalam melakukan proses komunikasi, maka memilih cara mana yang diambil untuk berkomunikasi sangatlah penting. Komunikasi menjadi bagian yang sanagat penting dalam kehidupan manusia. Ruang komunikasi adalah ruang dimana manusia yang terlibat saling menyampaikan gagasannya dan menarasikan pengalamannya dalam kehidupan sehari-hari. Dengan kata lain, komunikasi tidak dapat dipisahkan dalam kehidupan manusia (Wibomo, Wahyudin \& Benyamin, 2012). Karena ini berkaitan dengan media yang harus digunakan. Dibawah ini terdapat dua tatanan dalam menentukan efek apa yang ingin dicapai:

Komunikasi Tatap Muka, Komunikasi tatap muka dipergunakan apabila kita mengharapkan efek perubahan tingkahlaku (behaviour change) dari komunikan. Mengapa demikian karena sewaktu berkomunikasi memerlukan umpan balik langsung. Dengan saling melihat, kita sebagai komunikator bisa mengetahui pada saat kita berkomunikasi komunkan memperhatikan kita dan mengerti apa yang kita komunikasikan.

Komunikasi Bermedia: pada umumnya banyak digunakan untuk komunikasi informatif. Ketika tidak memerlukan efek dalam bentuk perubahan tingkah laku, maka dapat digunakan atau diambil media massa, jadi, tergantung dari situasi dan kondisi dan efek yang diharapkan (Uchjana, 2007 : 302-303).

Dalam konteks ini pencapaiannya adalah kesadaran dari masyarakat dalam menitipkan zakat maal oleh Unit Pengumpul Zakat (UPZ) Kecamatan Rancasari Kota Bandung sangat memerlukan suatu strategi komunikasi yang berkelanjutan. Teori ini menyebutkan bahwa aktivitas manajemen strategi terbagi dalam tiga tahapan proses yaitu formulasi, implementasi dan evaluasi. Tahap formulasi menekankan pada aspek perumusan rencana sebelum memulai suatu kegiatan. Tahap ini juga mencakup kegiatan pembagian tugas dan fungsi masing-masing elemen yang terlibat dalam pelaksanaan suatu kegiatan. Tahap implementasi menekankan pada aspek realisasi rencana yang telah dibuat berdasarkan job deskripsion masing-masing elemen. Tahap implementasi ini juga mencakup 
Strategi Komunikasi Untuk Meningkatkan Kesadaran Masyarakat dalam Membayar Zakat Maal pengontrolan terhadap pelaksanaan rencana. Sedangkan tahap evaluasi adalah tahap evaluasi terhadap capaian dan pelaksanaan kegiatan yang telah direncanakan.

Berdasarkan penjelasan diatas dapat dipahami sebuah tindakan aksi atau kegiatan yang dilakukan oleh seseorang atau perusahaan untuk mencapai sasaran atau tujuan yang telah di tetapkan. Sebagaimana yang telah diketahui bahwa Manajemen Komunikasi, Manajemen merupakan proses yang khas yang bertujuan untuk mencapai suatu tujuan dengan efektif dan efisien menggunakan semua sumber daya yang ada. Dengan begitu strategi komunikasi merupakan paduan dari perencanaan komunikasi, dimana perencanaan merupakan fungsi dasar dari proses manajemen serta manajemen komunikasi, manajemen komunikasi disini bisa diartikan sebagai aktivitas atau fungsi dari seorang.

Adapun tujuan komunikasi lewat pesan-pesan yang disampaikan dalam mensosialisasikan sesuatu terbagi menjadi empat menurut Marhaeni Fajar (2009: 60-61) : (1) Efek Kognitif, perubahan pendapat: dalam komunikasi berusaha menciptakan pemahaman yang dalam hal ini ialah kemampuan memaham pesan secara cermat sebagaimana dimaksudkan oleh komunikator. Setelah memahami apa yang dimaksud komunikator maka akan tercipta pendapat yang berbedabeda bagi komunikan. (2) Efek Afektif, perubahan Sikap: seorang komunikan setelah menerima pesan kemudian sikapnya berubah, baik positif maupun negative. (3) Efek Perilaku, komunikasi bertujuan untuk mengubah peilaku maupun tindakan seseorang. (4) Perubahan Sosial: membangun dan memelihara ikatan hubungan dengan orang lain sehingga menjadi hubungan yang makin baik.

Manajemen strategi komunikasi berkaitan dengan tindakan komunikasi yang dilakukan untuk target-target komunikasi dalam suatu terget perubahan. Strategi ini dilakukan baik secara internal maupun eksternal. Menjalankan strategi komunikasi strategi dengan baik merupakan kombinasi terbaik dari semua elemen komunikasi mulai dari komunikator, pesan, saluran (media), penerima sampai pada pengaruh (efek) yang dirancang untuk mencapai tujuan komunikasi yang optimal (Herman, 2017: 57).

Menurut Brennan dalam Effendy (2007: 112) komunikasi internal sebagai pertukaran gagasan diantara para administrator dan karyawan dalam suatu perusahaan, dalam struktur lengkap yang khas disertai perukaran gagasan secara horizontal dan vertical didalam perusahan, sehingga pekerjaan berjalan (operasi dan manajemen). Sehingga dapat disimpulkan bahwa komunikasi internal adalah komunikasi yang terjadi antara atasan dan bawahan, atau sebaliknya antara karyawan dengan atasan, atau antara karyawan dengan karyawan dalam suatu perusahaan.

Menurut Effendy (2007 : 128) komunikasi eksternal adalah komunikasi antara pimpinan organisasi dengan khalayak diluar organisasi. Komunikasi eksternal terdiri dari dua jalur secara timbal balik, yakni: Komunikasi dari 
Asep Sudarman

organisasi kepada khalayakdanKomunikasi dari khalayak kepada organisasi.

Sesuai dengan sifat dan karakter permasalahan data yang diangkat dalam penelitian ini, maka penelitian ini menggunakan paradigma interpretatif, menurut Morissan paradigma interpretatif merupakan paradigma yang dilakukan dengan menginterpretasikan karya seni berdasarkan sudut pandang pengamat, baik dari kesamaan pengalaman, unsur estetis, dan pengetahuan yang dimiliki oleh pengamat.

Proses peneltian ini menggunakan metode penelitian deskriptif kualitatif. Deskripsi merupakan pemaparan peristiwa atau situasi. adapun deskriptif dalam penelitian ini digunakan untuk menggambarkan berbagai fenomena atau gejala yang di amati saat penelitian, baik melalui catatan lapangan (field notes). Deskriptif dalam penelitian kualitatif dilakukan secara lebih mendalam dan disusun dengan dirinci baik dari sudut pandang peneliti subjek yang diteliti (Wirjokusumo \& Anshori, 2009: 3) Metode ini bertujuan memahami realitas sosial dengan dunia apa adanya bukan dunia yang seharusnya.

Digunakannya metode deskriptif kualitatif yaitu untuk menganalisis data berupa kata-kata yang diperoleh dari wawancara kepada nara sumber, sekaligus mendeskripsikan tentang fenomena yang ada dilapangan. Yaitu terkait tentang strategi komunikasi Unit Pengumpul Zakat (UPZ) Kecamatan Rancasari Kota Bandung dalam meningkatkan kesadaran menitipkan zakat maal, sehingga dengan begitu pendeskripsian tentang strategi komunikasi Unit Pengumpul Zakat (UPZ) Kecamatan Rancasari Kota Bandungakan mudah dipahami.

Penelitian ini menggunakan jenis kualitatif karena metode kualitatif sebagai prosedur penelitian yang menghasilkan data deskriptif berupa kata-kata tertulis atau lisan dari orang-orang dan perilaku yang diamati untuk diarahkan pada latar dan individu bolistic. Penelitian disini bermaksud untuk memahami dan mendeskripsikan fenomena yang ada di Unit Pengumpul Zakat (UPZ) Kecamatan Rancasari Kota Bandung, manajemen komunikasi yang digunakan, bentuk komunikasi yang dipakai, dan sosialisasi dalam mengumpulkan zakat maal.

Penelitian ini bermaksud untuk mencoba menggali dan memaparkan kegiatan yang dilakukan oleh Unit Pengumpul Zakat (UPZ) Kecamatan Rancasari Kota Bandung dalam meningkatkan kesadaran untuk membayar Zakat Maal menggunakan pendekatan komunikasi dengan didasarkan teori manajemen komunikasi internal dan eksternal. Dipakainya teori manajemen komunikasi didasarkan pada pertimbangan bahwa teori ini dipandang lebih tepat untuk menjawab rumusan masalah yang ada pada penelitian ini. Unit Pengumpul Zakat (UPZ) Kecamatan Rancasari Kota Bandung adalah lembaga nonstruktural bertugas sebagai pengumpul zakat dari masyarakat yang dimungkinkan dalam realitasnya menemukan kesenjangan dengan apa yang telah direncanakan, sebagaimana Badan Amil Zakat Nasional mempunyai visi dan misi dalam 
Strategi Komunikasi Untuk Meningkatkan Kesadaran Masyarakat dalam Membayar Zakat Maal pengumpulan dan penyaluran. Terlebih dalam penyaluran dana zakat maal dan juga untuk membagikan dana zakat yang terkumpul kepada mustahik tentunya untuk menjaga kestabilan antara pengumpulan dan penyaluran dana zakat terkhusus zakat maal yang ada di Unit Pengumpul Zakat (UPZ) Kecamatan Rancasari Kota Bandung sudah memungkinkan harus ada manajemen, terlebih dalam persoalan manajemen komunikasi.

\section{Analisis Strategi Komunikasi dalam Perencanaan Unit Pengumpul Zakat.}

Perencanaan dalam pengelolaan zakat dilakukan agar bagaimana cara Sumber daya manusia yang berkualitas dan memeliki keterampilan serta berdaya saing ini mampu untuk bekerja. Keterkaitan dengan hal itu adapun kondisi atau masalah ayang masih membelengu sampai sekarang ini, yakni mengenai kemiskinan yang melanda Indonesia. Dapat diketahui, kurangnya lapangan pekerjaan di berbagai sector ekonomi juga termasuk dampak dari kemeskinan, akibat krisis ekonomi yang berkepanjanagan mengakibatkan kesempatan kerja rendah terutama bagi perguruan tinggi, yang mana tak sesuai dengan target. Semakin banyak lulusan perguruan tinggi tetap saja kesempatan kerja rendah (Zainal, 2014: 17).

Rencana yang dilakukan oleh unit pengumpul zakat Kecamatan Rancasari Kota bandung biasanya mulai dari musyawarah awal untuk kemudian di implementasikan. Mulai dari menginventarisis kelurahan-kelurahan di Kecamatan Rancasari Kota Bandung. Di Kecamatan Rancasari Kota bandung ada empat (4) kelurahan diantaranya: Kelurahan Cipamokolan, Kelurahan Manjahlega, Kelurahan Darwati, dan Kelurahan Mekarjaya yang selanjutnya akan diakomodir tiap wilayah oleh Dewan Kemakmuran Masjid setempat, kemudian di laporkan pada Unit Pengumpul Zakat kecamatan. Inilah yang biasanya dilaksanakan dalam musyawarah anggota Unit Pengumpul Zakat.

Strategi yang dikembangkan diatas biasanya untuk mengatasi isu strategis tentang zakat, seperti menjelaskan resspon masyarakat terhadap informasi atau kebijakan zakat oleh Unit Pengumpul Zakat Kecamatan Rancasari Kota Bandung dari Badan Amil Zakat Nasional. Jika pendekatan sasaran bagi isu strategis yang diambil, strategi akan dikembangkan untuk mencapai sasaran, atau jika pendekatan visi keberhasilan yang diambil, strategi akan dikembangkan untuk mencapai visi dalam pengumpulan zakat.

Peran ketua Unit Pengumpul Zakat dalam kegiatan perencanaan pengumpulan dana zakat sangat penting dalam pelaksanaan seluruh kegiatan, terutama ketua menampung saran dan masukan dari setiap anggota untuk kemudian dimusyawarahkan serta diaplikasikan. Kegiatan perencanaan memerlukan penunjang dibidang kepemimpinan yang berwibawa, kepemimpinan yang dapat mencairkan suasana organisasi serta dapat mengayomi anggotanya.

Keahlian Personal seorang ketua Unit Pengumpul Zakat yang utama adalah kemampuan untuk bekerja sama, memahami, dan memotivasi individu 
lain, baik secara individual maupun dalam kelompok. Banyak individu berbicara secara teknis, tetapi tidak berbicara secara antarpersonal. Para anggota Unit Pengumpul Zakat mungkin merupakan pendengar yang buruk, tidak mampu memahami kebutuhan mustahik dimasakini atau mempunyai kesulitan dalam menangani konflik.

Terkait dengan kebutuhan fungsional ilmu komunikasi didalam upaya menciptakan atau knowledge worker dibidang komunikasi. Knowledge worker adalah tenaga komunikasi yang memiliki wawasan teoritis tentang komunikasi dan memiliki keterampilan dalam mengaplikasikan ilmu tersebut. Dalam studi manajemen pembekalan meaningful knowledge dan meaningful skills dapat dikonstruksi.

Kegiatan perencanaan yang lebih pada kegiatan eksternal dalam hal ini biasanya adalah pelaporan hasil dari penghimpunan dana zakat dan pendistribusian dana zakat. Dilapangan biasanya lebih pada realisasi program bidang dakwah, yang mencoba meramu kemasan yang selalu berkembang dan berubah untuk penyampaian program dan penyamaan persepsi diantara anggota Unit Pengumpul Zakat Kecamatan Rancasari.

Program ini agar dapat difahami oleh anggota Unit Pengumpul Zakat Kecamatan Rancasari pada Unit Pengumpul Zakat tingkat Kelurahan hingga Unit Pengumpul Zakat tingkat Rukun Warga dalam hal ini Dewan Kemakmuran Masjid. Biasanya Unit Pengumpul Zakat Kecamatan Rancasari mengakomodir Unit Pengumpul Zakat tingkat Kelurahan sesuai dengan kebutuhannya berdasar pada data mustahik yang terhimpun di masing-masing kelurahan yang mengacu pada Unit Pengumpul Zakat di tingkat wilayah Dewan Kemakmuran Masjid yang lebih detail mendata mustahik sehingga tepat sasaran.

Kegiatan perencanaan baik secara internal maupun secara eksternal perlu meninjau pula pada pemikiran tokoh Islam yang bergerak membangun peradaban umat. Salah satunya adalah Abu hanifah. Pemikiran Abu Hanifah terhadap zakat membawa konsep yang masih digunakan sehingga saat ini, yaitu mewajibkan zakat pada perhiasan emas dan perak. Orang yang berhutang tidak diwajibkan membayar zakat jika hutangnya lebih banyak daripada harta yang dimiliki (Sucipto, 2003: 5)Dalam kerjasama hasil pertanian (Muzāra'ah), kebijakan Abū Hanīfah meninggikan nilai kemanusiaan dengan melindungi pekerja lemah (Madhhabih, 1957: 182).

Unit Pengumpul Zakat Kecamatan Rancasari Kota Bandung selama sebelas bulan selain bulan Ramadhan dapat menyusun rencana untuk kembali mendata ulang harta kekayaan masyarakat sehingga terhimpun kelompok muqaki atau agniya dalam pengembangan pemberdayaan zakat mal.

Kegiatan sebelas (11) bulan kedepan lebih pada kegiatan penguatan sosialisasi dan pendataan mustabik dan juga muqakki untuk kepentingan penyaluran zakat mal. Dengan begitu masyarakat seara umum akan mengalami 
Strategi Komunikasi Untuk Meningkatkan Kesadaran Masyarakat dalam Membayar Zakat Maal perubahan pada pemahaman yang lebih baik khususnya dalam memahami zakat mal. Masyarakat lebih tersentuh baik secara perasaan atau pun pemikiran.

Efek yang ditimbulkan dari semua itu diantaranya: (1) Kesadaran, jika sebagian besar audience sasaran tidak menyadari merek, produk atau jasa, yang ditawarkan, tugas Unit Pengumpul Zakat adalah membagun kesadaran masyarakat. Kesadaran berarti bahwa pesan yang telah dibuat menimbulkan kesan kepada masyarakatyang kemudian dapat membantu mengidentifikasi pembuat pesan, mengarah untuk menyadari pentingnya membayar zakat mal. (2) Pengetahuan, masyarakat mungkin telah memiliki kesadaran, tetapi tidak mengetahui lebih banyak lagi. Dan memiliki tugas untuk memberikan informasi sebanyak-banyaknya sehingga masyarakat sebagai sasaran memiliki "pengetahuan tentang produk, manfaat, faedah guna, dan keuntungan", dalam membayar zakat mal.

Persoalan strategi komunikasi untuk menyadarkan msyarakat dalam membayar zakat mal merupakan perpaduan dari perencanaan komunikasi, dimana perencanaan merupakan fungsi dasar dari proses manajemen serta manajemen komunikasi, manajemen komunikasi disisni bisa diartikan sebagai aktivitas yang berlangsung proses komunikasi.

Proses menyadarkan masyarakat dalam membayarkan zakat mal oleh Unit Pengumpul Zakat Kecamatan Rancasari adalah bagian dari strategi penginformasian dan pendataan muzakki dan mustabik. Sehingga dalam hal ini murakki memiliki kecenderungan untuk membayar zakat mal disebabkan jelasnya informasi yang disampaikan juga jelas pula penyaurannya, jika suatu waktu ada keraguan dapat tabayyun dalam penyaluran yang tepat guna dan tepat sasaran.

\section{Strategi Komunikasi dalam Implementasi Unit Pengumpul Zakat.}

Menurut Joseph Dominick (2002), setiap komunikasi akan melibatkan delapan eleman komunikasi, yang meliputi: sumber, enkoding, pesan, saluran, dekoding, penerima, umpan balik, dan gangguan (Yuniarti, 2011).

Beberapa responden dalam pelaksanaan penyaluran zakat, baik zakat mal maupun zakat fitrah, biasanya mendapatkan informasi tentang zakat dari Ustad atau kyai melalui media pengajian di majelis ta'lim. Menyebarnya informasi terkait kebijakan zakat merupakan bagian dari hasil dari perencanaan tentang penyebaran informasi yang saat ini masih dalam tataran biasanya, yakni di forum majelis talim atau pengajian (Wawancara dengan Mustahik Zakat Kec. Rancasari, 22 Mei 2018).

Biasanya membayar zakat fitrah dan zakat mal kalau ada di titipkan saja di masjid, namun untuk zakat mal saya belum tahu besaran yang harus di bayar dan aspek apa yang harus saya zakati. Dalam penyaluran zakat, sampainya dana zakat itu pada mustahik, Insyaallah saya mudah-mudahan, yang terpenting niat saya 
menunaikan zakat (Wawancara dengan Mustahik Zakat Kec. Rancasari, 22 Mei 2018).

Kenyataan yang terjadi dilapangan jika dianalisa ternyata beberapa muzakki seperti berfikir ketika sudah membayar selsailah sudah tanpa harus menelusuri. Bukan berarti ini sebagai dari acuh dari para muzakki. Namun hasil penelusuran ternyata kesibukan dalam bekerja, media informasi dan sosialisasi yang kurang menjadikan sebagian muzakki sepenuhnya mempercayakan.

Data mustahik menurut beberapa responden bagusnya ada, saya jarang menanyakan sebab setelah saya membayar saya percayakan saja pada DKM. Saran saya untuk UPZ, lebih terbuka lagi mulai dari pendapatan dan penyaluran, saran saya dalam transparasi zakat perlu diinformasikan di tiap masjid sekecamatan Rancasari (Wawancara dengan Mustahik Zakat Kec. Rancasari, 22 Mei 2018).

Unit Pengumpul Zakat Kecamatan Rancasari Kota Bandung mulai dari peran ketua, sekretaris, bendahara juga anggota sudah sinergis. Ketua bertugas sebagai manajer yang menghimpun dan mengambil keputusan hasil musyawarah bersama anggota. Ketua Unit Pengumpul Zakat Kecamatan Rancasari Kota Bandung dalam setiap kegiatan dapat menjadi panutan serta menjadi penengah dikala terjadi konflik dilapangan (Wawancara dengan Mustahik Zakat Kec. Rancasari, 14 Mei 2018).

Implementasi dari perencanaan yang disusun biasanya setiap Tahun kegiatan dilakukan adalah pengumpulan dana zakat, dana zakat terkumpul kemudian harus sudah tersalurkan berdasar asnap Zakat. Namun dalam pelaksanaan dilapangan masih ada beberapa persen DKM yang memisahkan diri dengan Unit Pengumpul Zakat kelurahan dan Kecamatan. Sehingga kami belum bias mendata secara detail pendapatan dan penyalurannya. Permasalahan masih pada tataran sosialisasi yang berbenturan dengan kebiasaan masyarakat setempat, biasanya Dewan Kemakmuran Masjid setempat yang enggan untuk bergabung dengan Unit Pengumpul Zakat (Wawancara dengan Mustahik Zakat Kec. Rancasari, 14 Mei 2018).

Hasil wawancara dengan beberapa mustahik, terungkap bahwa biasanya pendataan secara formal oleh pihak Unit Pengumpul Zakat belum ada, terkait dengan pendataan mustahik, namun biasanya ada dari pihak Dewan Kemakmuran Masjid yang dibantu oleh pihak Rukun Warga dan Rukun Tetangga masing-massing. Begitu pun informasi dari petugas zakat masih pada tataran yang sudah lama dilakukan yakni penginformasian penerima zakat (Wawancara dengan Mustahik Zakat Kec. Rancasari, 14 Juni 2018).

Selama ini belum ada program pemberdayaan ekonomi masyarakat yang diinformasikan oleh petugas Unit Pengumpul Zakat dan belum ada pula pendataan secara berkala berkaitan dengan data mustahik pada tataran pendapatan bulanan untuk kemudian didata sebagai bahan yang nantinya 
Strategi Komunikasi Untuk Meningkatkan Kesadaran Masyarakat dalam Membayar Zakat Maal menjadi muzakki (Wawancara dengan Mustahik Zakat Kec. Rancasari, 14 Juni 2018).

Dana zakat diberikan masih pada tataran yang biasa pada akhir Ramadhan, dana zakat pun disalurkan melalui petugas dari Dewan Kemakmuran Masjid setempat. Dalam mendapatkan dana zakat pun hanya sebatas dating dan tidak perlu membawa Kartu Keluarga atau Kartu Tanda Penduduk sebagai tanda bukti penelusuran status pekerjaan mustahik.

Data yang dimiliki oleh Unit Pengumpul Zakat Kecamatan Rancasari Kota Bandung diharapkan menjadi bahan yang dapat dipertimbangkan oleh para muzakeki atau agniya dalam penyaluran zakat. Para muzakki atau agniya dengan adanya data sebaran mustahik zakat di tiap wilayah akan menjadikan suatu kepercayaan. Selain adanya data mustabik zakat transparansi dana pun perlu ada dan terpampang juga diinformasikan melalui media yang ada, baik secara konvensional yang melalui para ustad dalam ceramahnya atau pun dalam forum resmi.

Implemantasi dalam hal ini lebih pada kegiatan yang biasa dilakukan atau rutin khususnya dalam pengumpulan zakat fitrah. Namun zakat fitrah masih mencari formuasi yang tepat dalam pelaksanaannya. Kegiatan secara Internal biasanya pada event kegiatan 1 muharam yaitu santunan anak yatim, kegiatan ini selain di danai oleh infak dan shodaqoh dari para donator juga dianggarkan oleh pemerintah dalam hal ini kementrian agama, jika eksternal hanya sebatas laporan-laporan kegiatan pada Unit Pengumpul Zakat kecamatan pada tingkat kota (Wawancara dengan Mustahik Zakat Kec. Rancasari, 14 Juni 2018).

Abdul Mannan berpendapat bahwa ekonomi Islam itu berhubungan dengan produksi, distribusi, dan konsumsi barangdalam kerangka masyarakat Islam yang di dalamnya jalan hidup Islami ditegakkan sepenuhnya. Pada masalah "kelangkaan", Mannan berpendapat bahwa dalam ekonomi manapun, kelangkaan itu pasti terjadi dan dianggap sebagai masalah ekonomi (Wawancara dengan Mustahik Zakat Kec. Rancasari, 14 Juni 2018).

Merujuk pendapat Abdul Mannan zakat perlu dimaksimalkan dalam pemberdayaan ekonomi umat, sehingga perlu adanya kejelasan dalam jumlah yang didapatkan ketika pengumpulan. Akuntabilitas data dalam hal ini sangat diperlukan untuk kemudian ditinjau sejauhmana perkembangan mustahik setelah beberapa lama menerima penyakuran zakat, khususnya zakat mal.

Sekilas dapat dijelaskan mengenai pengurus (amil) yakni seseorang atau sekelompok orang yang dibentuk oleh masyarakat dan di sahkan oleh pemerintah untuk mengelola pelaksanaan ibadah zakat. Untuk menjadi amil harus memenuhi berbagai syarat berdasarkan syariat Islam yakni: a. Beragama Islam, b. Berakal dan baligh, c. Memiliki sifat yang amanah dan d. Mengerti dan faham tentang hukum-hukum zakat dan hal-hal lain yang terkait dengan tugas amil zakat (Sulistyani \& Rosidah, 2008: 100)

Implemantasi dari penyaluran zakat secara jangka panjang harus 
mengurangi kesenjangan sosial yang memperburuk perekonomian negara, kemiskinan yang akan terus meningkat. Pengembangan Sumber daya manusia ini dapat di artikan sebagai usaha untuk mempersiapkan orang-orang baik sebagai individu maupun sebagai anggota masyarakat dengan segala kedudukannya. Usaha yang dilakukan tidak hanya terbatas pada pembinaan atau sosialisasi saja, tetapi diimbangi juga dengan kemampuan fisik serta mentalnya sebagai pendukung. Dengan demikian Sumber daya manusia dapat memepersiapkan keterampilan seseorang agar dapat memenuhi kebutuhan hidupnya serta apa yang ditangunggnya dan memepersiapkan seseorang untuk mampu berkecimpung langsung dalam masyarakat (Meldono, 2009 : 52).

Unit Pengumpul Zakat Kecamatan Rancasari Kota Bandung selain program unggulan berupa santunan pada anak yatim dan asatidz, kami pun mensetting anggaran yang diterima dari pemerintah dalam membantu orang sakit, membangun mushola juga event atau kegiatan keagamaan di kecamatan Rancasari (Wawancara tanggal 14 Mei 2018).

Implementasi pengembangan ekonomi zakat membutuhkan keterlibatan pemerintah, muzakki dan mustahik. Semua pihak harus peduli dan bekerja keras dalam mewujudkannya. Jika tidak, berarti sama saja dengan membiarkan ketidakadilan ekonomi terjadi. Pengelolaan secara profesional dapat meningkatkan kesadaran muzakki dalam penunaian zakat. Karena masih ada umat Islam yang kaya (mampu) belum menunaikan ibadah zakatnya, bukan karena persoalan kemampuan, akan tetapi karena kurangnya pengetahuan dan kesadaran berzakat. Penunaian zakat akan membangkitkan solidaritas sosial, mengurangi kesenjangan sosial dan pada gilirannya akan mengurangi derajat kejahatan di tengah masyarakat. Untuk ini, pemerintah, Badan Amil Zakat atau Unit Pengumpul Zakat harus memiliki data base mengenai muzakki dan mustahik di wilayah kedudukannya.

\section{Strategi Komunikasi dalam Evaluasi Pengelolaan Unit Pengumpul Zakat}

Evaluasi berperan penting dalam peningkatan pengelolaan zakat. Evaluasi adalah tahap akhir dalam manajemen strategis. Tiga kegiatan pokok dalam evaluasi adalah (1) Mengkaji ulang faktor-faktor eksternal dan internal yang menjadi landasan perumusan strategi yang diterapkan dari waktu ke waktu dalam pengumpulan, penyaluran dan evaluasi dana zakat. (2) Mengukur kinerja personil atau petugas atau amil zakat yang bekerja mulai dari pengumpulan, penyaluran dan evaluasi. (3) Melakukan tindakan-tindakan korektif yang berujuan untuk meningkatkan kinerja.

Selaras dengan uraian diatas Unit Pengumpul Zakat Kecamatan Rancaasri Kota Bandung dari segi evaluasi lebih menitik beratkan pada sosialisasi. Dalam hal penghimpunan dan penyaluran zakat tidak terlalu dipermasalahkan sebab didukung oleh kinerja anggota yang tersebar ditiap kelurahan sampai pada 
Strategi Komunikasi Untuk Meningkatkan Kesadaran Masyarakat dalam Membayar Zakat Maal tingkat Dewan Kemakmuran Masjid. Penyaluran tidak terlalu menjadi kendala sebab sudah terdata mustahik dari Dewan Kemakmuran Masjid tiap wilayah (Wawancara dengan Pengurus UPZ Kec. Rancasari, 15 Mei 2018).

Analisis strategi berdasarkan konsep Fred R. David terdapat tiga tahap untuk menentukan strategi utama yang bertujuan untuk menyimpulkan informasi dasar yang diperlukan untuk merumuskan strategi-strategi yaitu (1) Bertujuan untuk memunculkan strategi-strategi alternatif yang dapat dilaksanakan melalui penggabungan faktor eksternal dan internal dalam pengumpulan zakat. (2) Bertujuan untuk menggunakan input informasi dari tahap 1 untuk mengevaluasi secara objektif strategi-strategi alternatif dari hasil tahap 2 yang dapat diimplementasika, sehingga bisa memberikan suatu basis objektif bagi pemilihan

Pemanfaatan media massa dan media social belum maksimal dilakukan, sementara masih pada sosialisasi bentuk forum dan laporan dalam bentuk surat menyurat. Dulu sempat membuat blog namun di kami belum ada SDM yang focus untuk menangani itu. Kedepannya sosialisasi akan dilaksanakan pula dengan media sosial yang harapannya memudahkan dalam penyampaian program. Misalnya membuat Whatsupp group khusus untuk anggota Unit Pengumpul Zakat mulai dari tingkat kecamatan, kelurahan sampai pada tingkat $\mathrm{Rt} / \mathrm{Rw}$ yang digunakan untuk mempermudah menampung aspirasi, sebaliknya bagi kami pun menjadi mudah dalam mensosialisasikan program terbaru dari UPZ keamatan pada upz kelurahan (Wawancara dengan Pengurus UPZ Kec. Rancasari, 15 Mei 2018).

Komunikasi bermedia ini pada umumnya banyak digunakan untuk komunikasi informatif. Ketika tidak memerlukan efek dalam bentuk perubahan tingkah laku, maka dapat digunakan atau diambil media massa, jadi, tergantung dari situasi dan kondisi dan efek yang diharapkan (Mulyana, 2007: 267).

Saluran komunikasi ini tak lepas dari peran komunikator yang dalam hal ini adalah para anggota dari Unit Pengumpul Zakat Kecamatan Rancasari Kota bandung dalam menyampaikan pesan, Unit Pengumpul Zakat Kecamatan Rancasari Kota bandung sebagai komunikator mempunyai peranan penting. Onong Uchjana Effendy mengartikan komunikator adalah pihak yang mengirimkan pesan kepada khalayak. Oleh karena itu, komunikator biasa disebut pengirim, sumber, soure, atau encoder (Effendy, 2003:304)

Secara stuktural Unit Pengumpul Zakat Kecamatan Rancasari Kota Bandung berada dibawah naungan pemerintah yang dalam hal ini adalah Kementrian Agama. Pelaksanaan zakat oleh negara akan menunjang terbentuknya keadaan ekonomi yang growth with equity, peningkatan produktivitas yang dibarengi dengan pemerataan pendapatan serta peningkatan lapangan pekerjaan bagi masyarakat.

Sumber-sumber pendapatan negara pun disesuaikan dengan yang dianut oleh kerajaan-kerajaan lainnya terutama dari sektor pajak atau bahkan upeti. 
Asep Sudarman

Penggunaannya pun semakin jauh dari ruh zakat itu sendiri (Wibowo, 2008: 6). Golongan penguasa dan fuqaha sepanjang abad pertengahan tidak mempertautkan petunjuk umum Alquran tentang dasar-dasar keadilan sosial dan ekonomis masyarakat dengan institusi zakat. Maka dari itu itu prinsip sosioekonomis melalui institusi zakat tidak dilegislasikan dan diimplementasikan dalam suatu sistem kehidupan ekonomi masyarakat muslim (Rahman, 1989: 5758).

Berdasarkan uraian diatas dalam pengelolaan zakat baik zakat fitrah dan zakat mal evaluasi strategi perlu dilakukan karena keberhasilan saat ini bukan merupakan jaminan untuk keberhasilan di hari esok. Keberhasilan selalu menciptakan masalah-masalah baru dan berbeda, organisasi-organisasi yang cepat puas diri akan mati dengan sendirinya. Dengan membina komunikasi interaksi antara anggota Unit Pengumpul Zakat Kecamatan Rancasari Kota Bandung lintas tingkat birarki tersebut, manajemen strategis membantu Unit Pengumpul Zakat untuk berfungsi sebagai tim yang menjadi lebih baik. Dengan menjaga komunikasi dan interaksi antar anggota Unit Pengumpul Zakat lintas tingkat hirarki, manajemen strategi membantu sebuah perusahaan untuk menjadi suatu tim yang kompetitif.

Evaluasi terhadap pelaksanaan pengumpulan dan pendistribusian dana zakat yang dapat dikemukakan sebagai bagi pengembangan subdisiplin ilmu manajemen komunikasi didalam dewasa ini yang diterapkan dalam kegiatan Unit Pengumpul Zakat Kecamatan Rancasari Kota Bandung.

Alasan tersebut adalah (1) Terkait dengan Unit Pengumpul Zakat Kecamatan Rancasari Kota Bandung dalam memanaje komunikasi dalam pelaksanaan kerja, menurut Soesanto (1976), komunikasi tersebut bertujuan untuk menciptakan keharmonisan diantara pelaku-pelaku komunikasi di lingkungan Unit Pengumpul Zakat Kecamatan Rancasari Kota Bandung. Pola tindakan komunikasi untuk mencapai itu semua bukan hanya reaktif sematamata, tetapi juga harus penuh dengan strategi. Manajemen komunikasi yang menggabungkan antara pendekatan manajemen dengan pengelolaan komunikasi memungkinkan kita untuk mewujudkan keharmonisan dalam komunikasi yang kita lakukan. (2) Didasarkan pada karakteristik ilmu komunikasi. Karakteristik ilmu komunikasi antara lain bersifat irreversible, kompleks, berdimensi sebab akibat, dan mengandung potensi problem. Dilihat dari karakteristik tersebut suatu proses komunikasi sangatlah rumit. Maka suatu tindakan Unit Pengumpul Zakat Kecamatan Rancasari Kota Bandung dalam komunikasi haruslah dikelola secara tepat. Disinilah subdisiplin manajemen komunikasi dapat memberikan kontribusinya (3) Terkait dengan kebutuhan fungsional ilmu komunikasi didalam upaya menciptakan atau knowledge worker oleh Unit Pengumpul Zakat Kecamatan Rancasari Kota Bandung Knowledge worker adalah tenaga komunikasi yang memiliki wawasan teoritis tentang tugas pokok dan fungsinya sebagai amil 
Strategi Komunikasi Untuk Meningkatkan Kesadaran Masyarakat dalam Membayar Zakat Maal zakat dan memiliki keterampilan dalam mengaplikasikannya. Dalam studi manajemen pembekalan meaningful knowledge dan meaningful skills dapat dikonstruksi. (4) Adanya asumsi peran ilmu manajemen akan semakin dominan dalam abad ke-21 sementara peran ilmu komunikasi akan semakin dibutuhkan dalam era globalisasi. Berdasarkan asumsi tersebut, maka kedua disiplin ilmu ini bersinergi dalam memecahkan berbagai persoalan sosial berkenaan dengan zakat mal di masa sekarng dan akan datang.

Evaluasi strategi Unit Pengumpul Zakat Kecamatan Rancasari Kota Bandung memiliki tiga aktifitas yang fundamental, yaitu mereview faktor-faktor internal dan eksternal yang menjadi dasar untuk strategi saat ini. Mengukur performa dan mengambil langkah dari Unit Pengumpul Zakat Kecamatan Rancasari Kota Bandung. Fred R. David lebih menjelaskan strategi utama suatu organisasi, penjelasan tersebut dilakukan tiga tahapan kerangka kerja dengan matrik sebagai model analisisnya. Matrik-matrik tersebut disesuai dengan segala ukuran dan tipe organisasi, sehingga dapat dipakai dalam mengidentifikasi, mengevaluasi, dan memilih strategi-strategi yang paling tepat untuk kegiatan Unit Pengumpul Zakat Kecamatan Rancasari Kota Bandung dengan harapan timbulnya kesadaran masyarakat untuk membayar zakat mal.

Secara Undang-undang dapat diilustrasikan bahwa terwujudnya Undangundang Zakat ini berasaskan syariat Islam; amanah; kemanfaatan; keadilan; kepastian hukum; terintegrasi; dan akuntabilitas. Dari asas ini dapat diketahui bahwa kemunculan Undang-undang zakat ini dalam rangka untuk meningkatkan efektivitas dan efisiensi pelayanan dalam pengelolaan zakat; dan meningkatkan manfaat zakat untuk mewujudkan kesejahteraan masyarakat dan penanggulangan kemiskinan, hal tersebut tercemin dari tujuan pengelolaan zakat dalam Undangundang ini (Pasal 02 \& 03 UU RI No. 23 tahun 2011).

\section{PENUTUP}

Perencanaan komunikasi Unit Pengumpul Zakat Kecamatan Rancasari Kota Bandung, merupakan pelaksanaan fungsi dasar dari proses manajemen komunikasi bisa diartikan sebagai aktivitas yang berlangsung proses pengelolaan Zakat Mal sehingga timbul kepercayaan masyarakat untuk membayar. Perencanaan baik secara internal dan eksternal didukung oleh peran ketua yang menjalankan komando organisasi dengan mengoptimalkan bidang-bidang yang ada dalam kelembagaan Unit Pengumpul Zakat Kecamatan Rancasari Kota Bandung.

Pelaksanaan implementasi Unit Pengumpul Zakat Kecamatan Rancasari masih pada kegiatan diluar zakat mal. Implementasi secara internal menguatkan kembali hasil perencanaan, namun adanya beberapa kendala dilapangan disebabkan kebiasaan masyarakat setempat sehingga kepercayaan kepada Unit Pengumpul Zakat masih kurang.

Unit Pengumpul Zakat Kecamatan Rancaasari Kota Bandung dari segi 
evaluasi lebih menitik beratkan pada sosialisasi. Sebab pada pengumpulan dan penyaluran didukung oleh kinerja anggota yang terssebar ditiap kelurahan sampai pada tingkat Dewan Kemakmuran Masjid. Kegiatan sosialisasi pun masih pada tataran penyampaian secara verbal pada kumpulan atau forum tertentu.

Perncanaan masih terfokus pada zakat fitrah namun kedepannya disarankan untuk mengelola langsung zakat mal dengan perencanaan menginventarisis hatra atau tingkat ekonomi dari masyarakat Kecamatan Rancasari selama sebelas (11) bulan di luar bulan Ramadhan. Sehingga dapat diidentifikasi setiap asnap zakat sebagai bahan untuk penyaluran.

Implementasi yang perlu dilaksanakan Pendataan mustabik dan muzakki sangatlah penting untuk kelangsungan hidup umat yang dikuatkan dengan transparansi keungan yang selalu diinformasikan kepada masyarakat melalui media massa dan media sosial selain itu perlu ditingkatkan pula profesionalitas amil dalam menjalankan tugasnya, sehingga timbul kepercayaan dari masyarakat terhadap Unit Pengumpul Zakat Kecamatan Rancasari Kota Bandung.

Pemanfaatan media massa dan media social belum maksimal dilakukan. Misalnya membuat Whatsupp group khusus untuk anggota Unit Pengumpul Zakat mulai dari tingkat kecamatan, kelurahan sampai pada tingkat $\mathrm{Rt} / \mathrm{Rw}$ yang digunakan untuk mempermudah menampung aspirasi, sebaliknya bagi kami pun menjadi mudah dalam mensosialisasikan program terbaru dari Unit Pengumpul Zakat Kecamatan pada Unit Pengumpul Zakat kelurahan.

\section{DAFTAR PUSTAKA}

Anggraningrum, D.N. (2014). Strategi Komunikasi Komunitas IndoRunners, dalam Jurnal Interaksi Online, 2(7), 1-9.

Ani \& Sulfiatni (2013). Strategi Komunikasi Petugas Penyuluh Lapangan Keluarga Berencana Dalam Mensosialisasikan Program Keluarga Berencana Di Kecamatan Medan Area. Jurnal ilmu komunikasi flow, 2(1).

Arifin, A. (1984) Strategi Komunikasi Sebuah Pengantar Ringkas, Bandung: Armico

Belch, G. E. \& Michael, E. B. (2007) Advertising and Promotion: An Integrated Marketing Communication Perspective, Fourth Edition, Mc-Graw Hill: New York,

Certo, S. C. \& Peter, J. P., (1990) Strategic Management: A Focus On Process, McGraw-Hill: New York

David, F. R. (2011) Strategic Manajement Konsep, Jakarta: Salemba Empat

Dinas Komunikasi dan Informasi. (2016). Pemkot Bandung Luncurkan Gerakan Ayo Bayar Zakat. diakses pada tanggal 12/12/2018 dari https://portal.bandung.go.id/posts/2016/05/30/vqvD/pemkotbandung-luncurkan-gerakan-ayo-bayar-zakat.

Effendy, O. U. (2007) Ilmu Komunikasi Teori dan Praktek, Bandung: PT. Remaja 
Strategi Komunikasi Untuk Meningkatkan Kesadaran Masyarakat dalam Membayar Zakat Maal

Rosdakarya.

Effendy, O. U. (2003) Ilmu Komunikasi Teori dan Praktek, Cetakan kesembilanbelas, Bandung: PT Remaja Rosdakarya.

Fajar, M. (2009) Ilmu Komunikasi: Teori dan Praktik, Yogyakarta : Graha Ilmu

Ginting \& Ellen (2013). Strategi Komunikasi Dan Tingkat Kesadaran Kesehatan

(Studi Korelasional Pengaruh Strategi Komunikasi Tim Penggerak PKK Pokja IV Terhadap Tingkat Kesadaran Masyarakat Mengenai Kesehatan di Kelurahan Dendang Kecamatan Stabat Kabupaten Langkat). Jurnal Ilmu Komunikasi Flow, 1(3).

Handoko, W. (2009). Isu Perempuan sebagai Strategi Komunikasi Politik Kampanye Calon dalam Pilkada, dalam Jurnal Yin Yang, 4(2).

Heddy \& Aruan, D.S. (2013). Strategi Debaters untuk Mengatasi Rintangan Komunikasi, dalam Jurnal Polimedia, 15(4).

Herman. (2017). Strategi Komunikasi Pengelolaan Zakat, Infak, dan Sedekah (ZIS) Melalui Media Sosial. Jurnal Communicatus: Jurnal Ilmu Komunikasi, 1(2), 53-70.

Hidayah, R. (2015). Strategi Komunikasi Lembaga Amil Zakat (LAZ) Swadaya Ummah dalam Meningkatkan Jumlah Muzakki di Pekanbaru. Jurnal Online Mahasiswa (JOM), 2(2).

Imran, M. (2008). Strategi Menghadapi Krisis di Era Globalisasi (Perspektif Komunikasi), dalam Jurnal LPPM Paradigma, 9(1).

Indrariani, E.A. (2011). Strategi Komunikasi Mahasiswa Asing dalam Interaksi dan Pembelajaran Bahasa Indonesia (Studi Kasus Mahasiswa Program Darmasiswa UNDIP Tahun 2010/2011), dalam Jurnal Parole, 2(1), 77-82.

Okprina. (2014). Strategi komunikasi pengawas pendidikan menengah di lingkup dinas pendidikan kabupaten gresik. Jurnal Inspirasi Manajemen Pendidikan, 4(4).

Prasetya, A.D. (2011). Strategi Komunikasi Dalam Penggalangan Dana Lembaga Swadaya Masyarakat "Kemitraan", dalam Jurnal Kom \& Realitas Sosial, 2(2).

Rahman, F. (1989) Neomodernisme Islam: Metode dan Alternatif, Penyunting: Taufik Adnan Amal, Bandung: Mizan.

Rahmawati, F.N., Suryandari, N., \& Kurniasari, N.D. (2013). Strategi Komunikasi•emberdayaan Ekonomi Perempuan Madura Berbasis Kearifan Lokal Madura, dalam Jurnal Komunikasi, 7(1), 33-42.

Rangkuti, F. (2009) Strategi Promosi yang Kreatif \& Analisis Kasus Integrated Marketing Communication, Jakarta: Gramedia Pustaka Utama

Satma. (2019). Strategi komunikasi kpu kota padang dalam meningkatkan partisipasi masyarakat pada pemilu kada tahun 2018. Ranah research : journal of multidisciplinary research and development, 1(2).

Wardani, R.W.K. (2017). Strategi Komunikasi Badan Amil Zakat Nasional dalam Pengumpulan Zakat Mal, dalam Jurnal Ilmu Dakwah: Academic Journal for Homiletic Studies, 11(1). 
Asep Sudarman

Werdiningsih, D. (2010). Strategi Komunikasi Penutur Anak dalam Interaksi dengan Berbagai Mitratutur pada Lingkungan Masyarakat Diglosik, dalam Jurnal Litera, 9(2), 103-121.

Wibowo, H.S., Wahyudin, U., \& Benyamin, P. (2012). Strategi Komunikasi Pemasaran. e-jurnal Mahasiswa, 1(1).

Wirjokusumo, I. \& Anshori, S. (2009) Metode Penelitian Kualitatif Bidang Ilmu-Ilmu Sosial Humaniora, Surabaya: Unesa University Press.

Yuniarti, T. (2011). Strategi Komunikasi Tvone dalam Penayangan Makelar Kasus Palsu, dalam Jurnal FKSB Makna, 2(2).

Zainal, V. R. (2014) Islamic Human Capital Management. Manajemen Sumber Daya Insani, Jakarta: PT. Raja Grafindo Persada. 